Бранислав Ивић

Универзитет у Београду

Православни богословски факултет

branislavivic95@gmail.com

https://doi.org/10.18485/rit.2021.19.35.9
УДК: 27-244.33-277

26-244.5-277

253.4

Оригинални научни рад

Датум пријема: 16.1.2021

\title{
ТУМАЧЕЊЕ ОС 2 У КОНТЕКСТУ РЕЛИГИЈСКЕ ПОЛЕМИКЕ СА ХАНАНСКИМ КУЛТОМ
}

\begin{abstract}
Резиме
Кьиїа йророка Осије сйаgа у збирку Дванаести йророка у канону Сйарой заве-

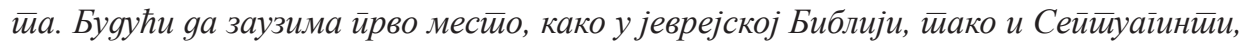

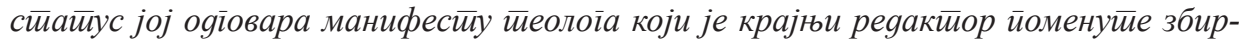
ке. Својом мейафором брака, као доминанйном иеемом ирвва иири йойлавља Кюиіе, Осија йокушава gа йокаже динамику оуноса Јахве и њеі̄ової изабраної народа који

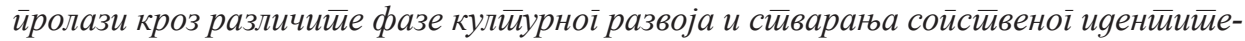

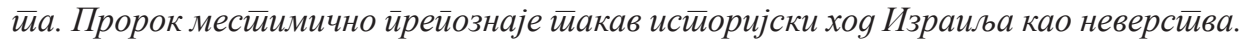

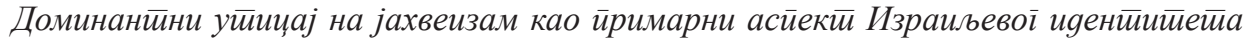
остиавила је хананска релиіијска ирракса, иоосебно кроз кулй боїа Баала и са њим у

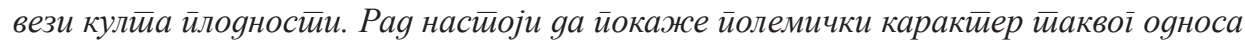
кроз ирример йумачења gруїе ілаве Књиіе ӣророка Осије.
\end{abstract}

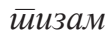

Кључне речи: Јахве, Баал, Осија, кулй йлоgносӣи, хананска релиїја, синкре-

\section{Брак пророка као оквир казивања}

Доминантна тема у оквиру одломка Ос 1-3 је метафора брак пророка. ${ }^{1}$

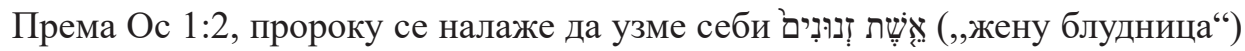

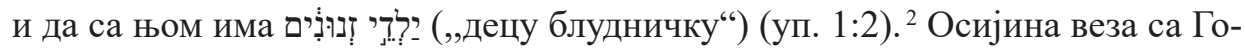
мером, као и именовање деце, разумевани су обично у контексту односа Јахвеа и неверног Израиља (1:10-2:23). Одломак Ос 3 онда описује пророчку приврженост прељубници, што се обично узима као симбол Јахвеовог од-

1 Интересантно је на пример да метафора брака за однос Јахвеа и Израиља у Ос 1-3 бива промењена родитељским односом који је доминантна, на пример, у Ос 11. Врло је важно да су обе представе засноване на догађајима Изласка. Синајски савез може бити представљен у категоријама брачних односа. Тако је Израиљево неверство Савезу оцењено као проституција (Изл 34:15-16; Понз 31:16).

2 Интересантно, када је реч о рођењу Јизраела, за њега се каже да му (=пророку) се роди (ל)), док се то не каже за друго двоје деце (уп. 1:6.8). 
носа и опроштаја према Изаиљу (3:4-5). ${ }^{3}$ Фраза дино у Књизи пророка Осије. Термин ституисање“, и као такав, у вези је са глаголом זנה ,починити блуд, про-

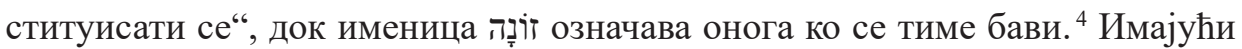
ово у виду, Ос 1:2 би се могло разумевати као наредба да Осија ожени жену која се повезује са проституцијом. ${ }^{5}$ Међутим, према неким истраживачима, овако нешто је неприхватљиво, посебно имајући у виду да је, рецимо, свештеницима ово било забрањено (уп. Лев 21:7, 13-14). ${ }^{6}$ Такође, поводећи се за немогућношћу прецизне историјске реконструкције, одређени истраживачи тврде да је прича алегорија. Ипак, новији истраживачи брак са Гомером посматрају као актуални догађај из живота пророка. Интересантно је објашњење по коме Гомера није ни проститутка, ни прељубница, већ јој се такво назвање приписује као припадници прељубничког народа - Израиља. ${ }^{7}$ Овакво објашњење, које Гомеру изузима од конкретних дела̂ прељубе, у супротности је са оним за шта се она терети у Ос 2:2. Тумачење је чак и проблематизовало брак пророка и Гомере, тврдећи да се није десила брачна, већ чисто сексуална веза која не подразумева брак, што је симбол Израиљевог прељубничког односа са Баалом. ${ }^{8}$ Можда је најбоље повести се за објашњењем које фокус проблема ставља, не на питање брака или пуке сексуалне везе, већ на симбол Израиљевог удаљења од Јахвеа што се представља категоријама прељубништва/проституције. ${ }^{9}$ Метафору брака и

3 У контексту повезивања Осијиног „личног“ живота и националне ситуације, врло је важан стих 3:1 где се пророку препоручује да воли своју жену „као што Јахве воли синове

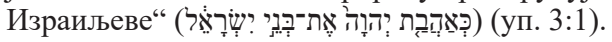

4 Уп. S. Van der Woude, Three Classical Prophets: Amos, Hosea, Micah, Richard Coggins et al. (прр), Israel's Prophetic Tradition: Essays in Honour of Peter R. Ackroyd, Cambridge University Press, 1982, 32-57, [46]. 42, [7].

5 УП. R. Routledge, Hosea's Marriage Reconsidered, Tyndale Bulletin 69.1 (2018):25-

6 Уп. Richard D. Nelson, Priestly Purity and Prophetic Lunacy: Hosea 1:2 and 9:7, y Lester L. Grabbe/Alice Ogden Bellis (прр), The Priests in the Prophets: The Portrayal of Priests, Prophets and other ReligiousSpecialists in the Latter Prophets (JSOTSup). T\&T Clark International, 2004, 115-33, [120-125].

7 УП. R. Routledge, Hosea's Marriage Reconsidered, 8-9.

8 Овакво тумачење Дејвис (Davies) заснива на читању глагола לק (,узети») као прељубу која, као таква, не подразумева нужно брачне оквире. Међутим, Дејвис (Davies) превиђа постојање предлога ?? у комбинацији са 뿞 која се на другим местима у Страом завету односи на ступање у брак (уп. Пост 24:3-4; 27:46; Изл 6:20, 23, 25; Лев 18:18; 21:7; Понз 21:11; 25:5; Суд 4:2-3; Јер 16:2; Рут 4:13. Уп. Graham I. Davies, Hosea (New Century Bible Commentary), Eerdmans Publishing Co, 1992, 19.

9 УП. S. Moughtin-Mumby, Sexual and Martial Metaphors in Hosea, Jeremiah, Isaiah, and Ezekiel (Oxford Theological Monographs), Oxford University Press, 2008, 215-224. 
прељубе ћемо посматрати као оквир који писац бира да би говорио о религијским праксама страних јахвеизму.

\section{Ханански бог Баал}

Метафора са љубавницима стоји у блиској вези са термином בעל (,баал““) који се појављује у различитим облицима кроз Оc 2. Термином је означена друга група ентитета̂ са којом је Јахвеова жена починила прељубу. Прецизна природа везе између група̂ означених као љубавници и Б/баала̂ није сасвим јасна. Једна од потешкоћа је и та што се термин „љубавници“ ( са суфиксом) појављују само у множини, док се теоним појављује, како у

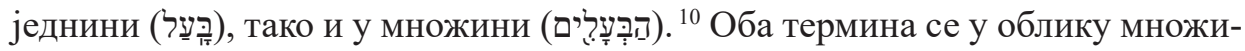
не користе у Oc 2:15. У наставку ћемо истражити статус бога Баала у хананској теолошкој мисли, а посебно са аспекта култа плодности. Имајмо у виду да аутор у Оc 2:8-9.22 директно проблематизује питања̂ извора плодности, негирајући Баала као заслужног за изобиље земаљске плодности.

Угаритско ${ }^{11}$ божанство одређено термином בע (,„господар“6) било је познато и под многим другим називима, ${ }^{12}$ при чему новија истраживања показују разликовање између (функционалног) теонима и личног божанског имена. ${ }^{13}$ Као божанство олује и плодности, повезиван је са сиријским Хададом и месопотамским Ададом, те је у значајном броју случајева именован јеврејским кореном hd/hdd (,„громовник“) одакле и повезивање са олујом. ${ }^{14}$ Име једне, од његове три, кћерке, tly ${ }^{15}$ ("Dewy One”/,Зорка“), указује на повезаност са метеоролошким феноменима. Осим тога, Баал тврди да поседује тајну грома (уп. ВC II:KTU 1.3 III.20-21 (71); IV.14-20 (72-73). Баа-

10 Уп. В. Е. Kelle, Hosea 2: Metaphor And Rhetoric in Historical Perspective (Academia Biblica (Series) (Society of Biblical Literature)), Society of Biblical Literature, 2005, 120.

11 Оваква атрибуција упућује на доминантву предност угаритских таблица откривених у Рас Шамри када је реч о обликовању Бааловог портрета.

12 УП. Nicolas Wyatt, The Titles of the Ugaritic Storm-God, Ugarit-Forschung 24, (2007), 403-424; A. Botica, "The Theophoric Element Ba'al in Ancient Phoenician Inscriptions", Perichoresis, vol. 10.1 (2012): 67-93, [72-76].

13 УП. Brian P. Irwin, «Baal and Yahweh in the Old Testament: A Fresh Examination of the Biblical and Extra-Biblical Data» (докторска дисертација), Toronto, 1999, 71.

14 УП. Nicolas Wyatt, The Titles of the Ugaritic Storm-God, Ugarit-Forschung 24, (2007), 412. Интересанто је и то да се у RTU:KTU 1.10 III.32-36 појављује Баалова титула h.tk dgn коју можемо превести као „владалац кише“; у ВC I:KTU 1.2 IV.8(336); BCII:KTU1.3 0.40 (69); BC I:KTU 1.1 III.18 (182); V.60; 1.19 (129) L43-44 (110) се назива rkb 'rp (,jахач облака“). Имајмо на уму да постоји унутрашња логика оваквом одређења с обзиром да су облаци „извори“" кише. У Расирави Асархаяона са Баалом оg Тира, Баал се назива b’1 şpn чиме се подразумева одговорност за поморске олује и потовања̂ ( $\left.A N E T^{3} 533-534\right)$

15 Уп. ВC II:KTU 1.3 III.5-8 (218-221); V.41-43 (344-349); 1.4 IV.54-57 (80); 1.5 V.10-11. 
лова повезаност са небеским светом претпоставља се у чињеници да Данил дозива управо њега како би му помогао да ухвате птицу за коју се мисли да носи остатке од Акат (RTU:KTU 1.19 III.1-3 (303-304)). Коначно, двоструко име Бааловог пратиоца Gupn-wa-Ugar (,Вино и Поље“) ${ }^{16}$ претпоставља да је Баал повезан са плодношћу - што је природна последица сматрања да је он божанство кише (BC II:KTU 1.3 III.36 (72)). Врло је важно и то да се за Баала везује и двоструко очинство. Наиме, проблем се јавља због тога што угаритски текстови говоре о њему као bn dgn (,„ин Дагона“), ${ }^{17}$ али и као bn '1 (,,син Ела“). ${ }^{18}$ Такође, интересантно је и то да угаритска листа богова помиње седам Баала̂. ${ }^{19}$ Ипак, нама је важно то што је Даган, један од два божанства која се помињу као Баалови очеви, по свему судећи, аутохтоно угаритско божанство чије име су западни Семити усвојили као назив за жито (dgn), при чему постоји мишљење према коме je bn dgn функционално одређење преко кога се Баал идентификује као божанство плодности, док је bn'l заправо указивање на Баалово синовство са Елом. ${ }^{20}$ Поред тога што се Баал представља првенствено као бог олује и плодности, он се такође јавља и као божанство рата или заштитника града. ${ }^{21}$ Међутим, он је слављен и као ратник - заштитник од непријатеља (RTU:KTU 1.119.26-36) који се са богом Јамом („море“) бори за превласт (KTU 1.1-1.2; Дан 7), а потом гради замак на гори Сафон, одакле Баал излива кишу на земљу (BC II:KTU 1.3-1.4;

16 УП. Sang-Youl Cho, Lesser Deities in the Ugaritic Texts and the Hebrew Bible: A Comparative Study of Their Nature and Roles (Deities and Angels of the Ancient World 2), Gorgias Press, 2007, 157-162.

17 Уп. BC I:KTU 1.2 I.19,35 (282); RTU:KTU 1.5 VI.23-24 (122); 1.6 I.6,51-52 (129); RTU:KTU 1.10 111.12,14 (220); RTU;KTU 1.1211 .26 (246); 1.14 II.25;IV.7 (185).

18 Уп. RTU:KTU 1.17 VI.2(270), али има и навода да је Ел његов отац (уп. ВC I:KTU 1.2 III.21 (254); ВC II:KTU 1.3 V.35 (74); 1.4 IV.47(80). УП. N.Ayali-Darshan, Baal, Son of Dagan: In Search of Baal's Double Paternity, Journal of the American Oriental Society, 133(4), 2013, 651-657.

19 Уп. RTU:KTU 1.47 11.5-11 (361); RTU:KTU 1.118 11.4-10 (412); 1.148 11.2-4 (427); RCU:KTU RS 20.24 II.4-10 (36). Вероватно је реч о већем броју манифестација божанства које у себи учитавају различите традиције. Постоји и објашњење по коме је реч о седам муња̂ (уп. RTU:KTU 1.101 I.3(388))

20 Више о овоме код N. Wyatt, The Titles, 408. Проблематично код овог објашњења је појава да се Баал често (уп. rtu:KTU 1.108 II.8,10 (388)) назива hotk dgn што већина истраживача преводи као „изданак Дагана“, док Вајат (Wyatt), тврдећи да глаголски корен h九tk значи „владати“, то назвање преводи као „владалац кишом“. Када је реч о Еловом очинству, имајмо у виду да управо он рида сазнавши да је Баал умро. Уп. RTU:KTU 1.5 VI.11-25 (123-125), али се и радује са првим индицијама о Бааловом васкрсењу (уп. RTU:KTU 1.6 III.14-2 (137)).

21 RTU:KTU 1.119 II.26-36 (418) садржи обред жртвовања који има за циљ да Баала присили да заштити град од нападача. Повезивања бога врема са прерогативима божанства рата није неуобичајено, посебно имајући у виду често везу насилне олује и напредовања војске. У египту и Асирији, на пример, монарси нису били противни повезивању своје застрашујуће војске са упечатљивим сликама грмљавине. Уп. Brian P. Irwin, «Baal and Yahwe”, 79. 
1.4 VI.3-6 (82); KTU 1.4 VII.25-37 (84)). ${ }^{22}$ Упркос победи над хаотичним божанством мора, његов статус и дозволу за изградњу дворца потврђује ипак Ел као врховни бог ханаског пантеона. ${ }^{23}$ Интересантно је и то да Баал, поражен од стране бога Мота („смрт“), умире, те је приморан да оде у доњи свет, али га његова сестра Анат избавља поразивши Мота (RTU:KTU 1.6.II.26-27 (134-135)). Реч је о алегорији за пољопривредну сезону, те тако персонификација олује у лику Баала устаје у одређено време.

\section{Ос 2 и KTU 1.16 III.2-8}

Упућивања или алузије на „Баала“ или „баале“ у Ос 2 појављује се у оквиру две текстуалне целине. Најпре у Ос 2:3-15, односно у Јахвеовом парничном говору против Израиља, којим се народ оптужује за своје неверство. Изариљ се сматра кривим због прељубе (2:3-7), при чему се у оптужбама, Jахвеу придружују и деца Ammi и Ruhamah (2:3-4). ${ }^{24}$ Казна неверној супрузи, мајци, односно народу представљена је у 2:8-10, 11-15, а означена упо-

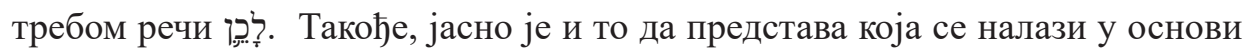
Oc 2 почива на вези између концепта брака и националног савеза са Јахвеовом. У вези са овим треба поменути Лев 26 где се каже да, између осталог, савез са Јахвеом подразумева и сезонске кише, као и плодност коју би оне поспешиле (Лев 26:4-5), мир у земљи (26:6a), предах од дивљих животиња (26:6b), али и пораст наталитета (26:9). Ускраћење ових добара присутна је у парничном говору у оквиру Oc 2:3-15. Тако, због одсуства кише Израиљ

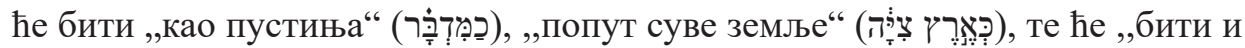

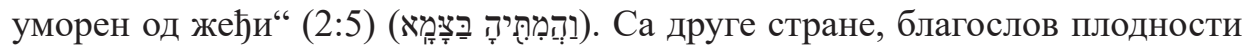
које је обећан у Лев 26:4b-5, сада се понавља Јахвеовом тврдњом да ће вра-

22 Епизода о градњи палате је једна од најважнијих у циклусу сукоба Баала и Мота. Није реч о градњи храма или неког другог богослужбеног места, већ о резиденцији младог божанства Баала, сина бога Ела. Он најпре тражи дозволу од своїа оияа, и то преко своје сестре Анат. Он најпре оклева, а онда Баал покушава преко своје мајке Ашере да оствари свој циљ. Она, како нам се казује, шаље једног из своје пратње богу заната̂ Kathir wa-Hasis, познат као Hayin („Брзи“) како би помогао око припрема̂ за градњу. Осим мноштва посуђа и свих луксузних ствари, од намештаја се помињу кревет, сто, столица и лапма (уп. 2Цар 4:10). Око Бааловог престола налази се балдахин и подножје за ноге владара. Мот је саботирао рад уз помоћ својих сарадника, затим долази до поновне молбе мајке и сестре оцу да Баал настави са радовима, што је на крају ипак успело. Палата је подигнута од кедровог дрвета са Ливана и Сириона. Уп. U. Cassuto, The Palace of Baal, Journal of Biblical Literature 61, no. 1 (1942): 51-5

23 Уп. Mark S. Smith, The Origins of Biblical Monotheism: Israel's Background and the Ugaritic Texts, Oxford University Press, 2001, 43-45.

24 H. G. May, An Interpretation of the Names of Hosea's Children, Journal of Biblical Literature, vol. 55, no. 4, 1936, 285-291, [287-289]. 


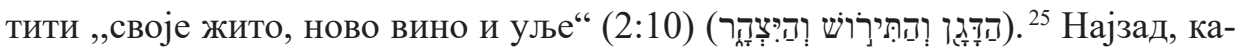

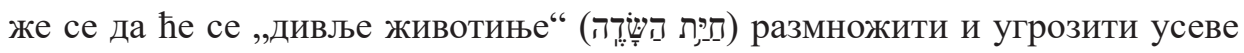
(уп. 2:14b), што је последица укидања благослова изнетог у Лев 26:6b и испуњења клетве из Лев 26:22.

Oc 2:7-8 сажима оптужницу против Израиља тврдећи да је ишао за љубавницима (уместо да је следовао Јахвеу) и мислио да су добра - хлеб, вода, вуна, лан, уље и пиће - дошла од њих (а не од Јахвеа, како и јесте). Врло је важно да су побројани продукти диретно, неки више, неки мање, зависни од временских фактора, односно божанстава времена и плодности. ${ }^{26}$ У конкретном случају, љубавници се идентификују са баалима (2:15), односно богом Баалом чије су кише биле од изузетне важности за ниво приноса продуката поменутих у Oc 2:7 (уп. RTU:KTU 1.6 III. 13-16 (137)). Са друге стране, Oc 2:23-24 може упоредити са RTU:KTU 1.16 III.2-8 (231), ${ }^{27}$ где болест цара Кирта доводи до суше, што је последица саосећања створења са царем или Киртовог заштитника Баала. ${ }^{28}$

25 Довођење ових производа у везу са савезом, уп. Понз 11:13-15. Ова фраза се појављује шеснаест пута у Старом завету (Понз 7:13; 12:17; 18:4; 28:51; 2Цар 18:32; Јер 31:12; Ос 2:24; Јл 1:10; 2:19; Аг 1:11; Нм 1:11; Нем 5:11; 10:40; 13:5; 13:12; 2Дн 32:28). У свим овим случајевима ова добра су знак Јахвеовог савеза и послушности Израиља. Изузетак је само 2Цар 18:32, где Равсак у обраћању народу Јерусалима помиње ова добра као долазећа од извора који није Јахве. Чак и на овом месту, покушано је са убећивањем народа да земља у коју ће бити одведени биће налик на оној коју им је Јахве дао.

26 Ово је подржано тврђењем у Ос 2:14 да вино и смокве (уп. Јер 5:17; Јл 1:17; Пс 105:33) Израиљ разумева као поклоне од својих љубавника, односно страних божанстава. Свакако, агрикултурални наподи се подразумевају, но сад их остављамо по страни.

27 Легенда о Керету, цару Хубура, позната и као Еп о Кирти је угаритска поема коjа се смешта у Касно бронзано доба (1500-1200). Сачувана је на три глинене таблице откривене 19030-31. године. Писана је угаритским клинастим писмом и приписује се Илимилку, првосвештенику, који је, такође, делимично и писар Циклуса о Баалу, као и Легенде о Акуат (KTU 1.17-1.19). Таблице се данас чувају у Musée National d'Alep у Сирији. Уп. B. Margalit, The Legend of Keret, y Wilfred G. E. Watson/Nocolas Wyatt (прр), Handbook of Ugaritic Studies, Brill Academic Publishers, 1999, 203-233.

28 Због оштећења није могуће утврдити узрок суше. У старозаветној књижевности, као и угаритским списима, забележен је одговор, на пример, земље на гнусне злочине. У јеврејској традицији, Адамов грех проузроковао је клетву земљи да ће рађати трње и коров (Пост 3:17-19), док занемаривање Савеза од стране људи доводи до тога да усеви неће успевати (Лев 26:20). Такође, Давидова наредба да се спроведе попис довела је до глади (2Сам 24:13). У свим од ових случајева, природа не делује спонтано, веч по Јахвеовој наредби. Слични примери се проналазе и угаритској књижевности, убиство Аката довело је до суше (KTU 1.19 II.1-25). У одломку о коме расправљамо, чини се да се суша јавља као последица одсуства Баала. У KTU 1.16 IV, чињеница да Ел наређује Бааловом гласнику да узвикује са врха високе куле може да подразумева одсуство Баала, те да се и сушта јавља због његовог одсуства (RTU:KTU 1.16 IV. 1-16 (232-234)). Овкав закључак је могуће донети и на основу паралела у вокабулару између наведеног одломка и KTU 1.5 IV.3-11 где слуге Гупн и Угар трагају за Баалом, својим одсутним господаром (уп. RTU:KTU 1.5 IV.3-5 (122-124) | RTU:KTU 1.16 IV. 3-4 (138)) 
„Уље које лије ${ }^{29}$ [из/у пехар(а)]

обратити пажњу, истражите ${ }^{30}$ земљу и небо;

Идите до обода земље,

до граница воде!

Истражите земљу због Баалове кише,

и поља због кише Вишњег!

Сјајна је за земљу Баалова киша,

и за поља, киша Вишњега;

сјајна за жито у браздама,

у обрађеном земљишту пшеничног усева,

над браздама усева!“

У тексту о Кирту, неименована особа је упитана да „истражи“ или „обрати пажњу“ на земљи и небу како би пронашла Баала. Сведочанства о божанској одсутности и степену суше уткана је у изјаву (II. 3-16 (228)) да су залихе „хлеба“ (lhm), ,вина“(yn) и „уља“ (究mn) исцрпљене. Иако се изразима разликују, свака од поменутих ставки има одговарајућег парњака у Ос

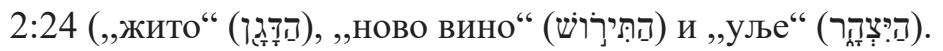

У овом контексту, врло је важан и одељак Ос 2:18-19 који, осим помена празника, иначе недвосмислено јахвеистичких, ${ }^{31}$ имамо тврдњу да се у надолазећој ери, која и означава престанак ,дане баала“, Јахве више неће називати во локалне манифестације Јахвеа или да је Јахве врховно божанство у пантеону нижих баала. Осим тога, могуће је и то да су Израиљци служили Јахвеу као Баалу. ${ }^{32}$

29 Иста формулација се појављује у ВC II:KTU 1.3.II.31 (70) и 1.104.14 (. Реч је о акту имитативне магије уз помоћ којег се подстичу та-ложење влаге која представља дебљину земље, односно њену плодност (уп. Бр 13:20). Уп. Ginsberg, H. L., W. F. Albright, and Elimelech, The Legend of King Keret: A Canaanite Epic of the Bronze Age, Bulletin of the American Schools of Oriental Research. Supplementary Studies, no. 2/3 (1946): 1-50, [46-47].

30 Због великих лакуна у тексту само се може претпоставити ко говори. Може бити да је у питању божанство, свештеник који делује у име Керета, Илху или пак Баалови гласници, што је случај у RTU:KTU 1.5.VI.3-9 (126). Засигурно да постоји веза између наратива о Керету и Баалових текстова, посебно имајући у виду повезивање смрти Баала и Киртуа. Чини се највероватнијим да говорник даје упутства Бааловим гласницима у вези са потрагом.

31 УП. Лев 23:2-44; Бр 10:10; 29:39; 2Цар 222-23; Ис 1:13-14; 66:23; Јез 4424; 45:17; Језд $3: 5$; Нем 10:33-34; 2Дн 2:3; 8:13.

32 Приписивање истих или сличних особина божанствима са различитим имениома била је уобичајена појава на Блиском истоку. Чини се да је то случај и са асирским богом Ададом за кога се, такође, сматрало да има моћ да кишом, односно плодношћу. Промена времена тумачена је као Ададова рика међу облацима. Осим тога, Дагон - божанство житарица и плодности усева - сматран је за Бааловог оца. 


\section{KTU 1.5 - 1.6: сукоб Баала и Мота}

Још један важан наратив везан за култ плодности у хананској теологији јесте сукоб Баала и Мота. ${ }^{33}$ Циклус прича̂ које мит обухвата тичу се напетости између плодности и јаловости у аграрном циклусу. ${ }^{34}$

Наиме, саградивши замак (KTU 1.3-1.4), на врхунцу своје моћи, Баал се пита да ли може да надвалада Мота, бога смрти, разарајућу силу суше и стерилитета. Преко своја два гласника Лозе и Поља (gpn w'ugr) ${ }^{35}$ позива Мота на прославу и проглашење своје суверености [над целим светом] речима (BC II: KTU 1.4..VII.45-52, (85)): ${ }^{36}$

Заиста ћу послати гласника божанском Моту,

Изасланика Еловом вољеном, хероју.

Мот може мрмљати за себе,

Вољени може смишљати планове у свом срцу,

(али) само сам ја онај који влада над боговима,

Онај који ће угодити боговима и људима,

Онај који ће задовољити мноштва̂ земље.

Ипак, ситуација се мења јер се гласници враћају са Мотовим претњама смрћу упућеним Баалу (RTU:KTU 1.5.I.1-8, 12-26 (116, 116-119)). Врло је важно да се истиче моменат суше (уп. 1.5.I.4 (115)), док у истом контексту може да буде и пронађен сезонски аспект мита јер, у оквиру космичких промена због Баалове неминовне смрти, биће спржен род маслине, плодови који расту на дрвету, али и на земљи (1.5.ІІ.2-6 (120)). Увенуће вегетације јавља се и као последица Бааловог страха и покоравања Моту коме он поново шаље гласнике (1.5.II.6-12 (121)) прослављајући га најпонизније. Након

33 Мот је хананско божанство смрти и подземног света. У угаритским тесктовима њему се приписује велико ждрело (npš) које незасито гута људе отпремајући их у подземни свет, сличан, по описима, Шеолу. Његове чељусти достижу до земље, усне до неба, а језик до звездаิ. Управо ће он прогутати Баала као што се гута маслина или неко воће (RTU:KTU 1.5.II.1-6 (120-121); Иc 5:14) .

34 УП. J. Gray, Legacy of Canaan: The Ras Shamra Texts and Their Relevance to the Old Testament, Brill Academic Publishers, 1965., 53.

35 Природа Баала као божанства плодности у директној је вези са његовим гласницима за које Баал каже да су синови Сенке коју је он оплодио (уп. ВC II:KTU 1.4.VII.53$56(85))$.

36 Треба рећи да се двапут говори о изазивању на двобој и самом двобоју, а Мот се у појављује у различитим улогама. У првом окршају, Мот је представљен као одговоран за летње суше изазивајући ,пожар“ неба и прђење земаљских плодова. Међутим, имајмо у виду да кише нестају јер Баал силази у доњи свет. УП. John C. L. Gibson, Canaanite Myths and Legends, T\&T Clark International, ${ }^{2} 1978,18$. 
великих лакуна у текстовима, у 1.5.V.6-17 (124) Баала коначно сусрећемо на путу ка подземном свету. Мот му заповеда:

Што се тебе тиче,

Узми своје облаке,

Своје ветрове, своје конопце (=муње), своје кише,

(узми) са собом својих седам божанских помоћника, ${ }^{37}$

Својих осам вепрова,

(узми) са собом Пидрај, ћерку Светлости,

(узми) са собом Талиј, ћерку Пљуска;

те управи своје лице ка планини моје гуше.

Узми планину на своје руке,

Брдо на своје дланове,

И сиђи у дом седишта земље,

Буди прибројан са онима који иду доле у земљу.

И знаћеш, боже, да си мртав.

Такође, врло је важно да Баал са собом у доњи свет води јуницу са којом је имао однос „,седам и осам“ пута на пољу šhlmmt и добио теле (RTU:KTU 1.5.V.17-22 (124-125)). ${ }^{38}$ Имајмо на уму да су се животиње сиријске пустиње, како то бележи Доти, париле током периода rabi'a или сезоне пашњака, када би трава расла захаваљујући раним кишама. Реч је о периоду априла и маја, пре јужних ветрова пред којим вегетација вене. Ово је време Баалове доминације. Осим тога, овде може бити речи о ритуалном венчању које стоји у позадини мита. ${ }^{39}$ На овај начин је означен почетак сезоне узгоја тако да све наредно потпада под окриље божанског промисла.

37 Као божанство ветра и времена, од кога зависе роса, киша и снег, Баал се спомиње у BC II:KTU 1.3.II.39-41 (73); 1.4.VI.6-7 (79); RTU:KTU1.5:V.8 (124); 1.16.III.5-7 (231); 1.101.7 (388).

38 RTU:KTU 1.5.V.17b-22 (124-125) је један од најзанимљивијих одломака у оквиру Бааловог цилуса. Индикативно је то да се за јуницу користи реч prt која је сродна библијском термину за јуницу $p r h$ (Oc 4:16; Ам 4:1). Мотив јунице се појављује и у RTU:KTU 1.10.III.2022 (157); 33-38 (158); 13.22-29 (160); 1.6.II.28-30 (135). Имајмо на уму да је јуница, крава, попут бика била врло важан симбол плодности. Тако акадски мит говори о јуници Amat-Sin и месечевом божанству, који се прерушава у бика и одводи јуницу са којим је имао однос, пославши јој са неба током порођаја две богиње које доносе воду и уље. Слична прича постоји и у хетитској теолошкој мисли, при чему се божанство овде прерушава у младића и са јуницом добија дете. Уп. Н. М. Barstad, The Religious Polemics of Amos: Studies in the Preaching of Amos 2,7B-8; 4,1-13; 5,1-27; 6,4-7; 8,14 (Supplements to Vetus Testamentum 34), Brill Academic Publisher, 1984, 46-47.

39 Сматра се да је Баалов наследник гарант одрживости Баалове плодности упркос његовом силаску у подземни свет. Уп. А. Botica, Weather, Agriculture, and Religion, 110. 
Након одељка од неких, приближно, тридесетак стихова који су изгубљени, а који вероватно описују смрт Баала, имамо нарицање Ела за њим (1.5.VI.825 (126-128)), као и потрагу за мртвим богом коју предузима Анат, Баалова сестра (1.5.VI.25-31 (128)). Анат га проналази (1.6.9-18 (130)) измоливши га од „Šp̌̌ светлости богова“ (1.6.11), ${ }^{40}$ а затим приређује погребну свечаност (1.6.18-29 (130)). Праксу оваквог типа осуђује Понз 26:14 где се првине плодова никако не дају за умрле. Можемо претпоставити да Понз 26:14 расправљају против овакве праксе, односно култа Баалу који је био присутан у Палестини и Сирији, а имао је елементе култа плодности. ${ }^{41}$ Умрлог Баала замењује, али не толико успешно, Аттар (1.6.I.15-37 (129-131)). Након великих недостатака у тексту, следи заузимање Анат код Мота да јој врати брата Баала (1.6.II.6-12 (133-134)), ${ }^{42}$ при чему Мот одбија то да учини. На крају, Анат ипак бива приморана да употреби силу (1.6.II.30-37 (135-136)):

Она [Анат] је зграбила Мота.

Са ножем она га је разделила;

Са вејалицом она га је разбацала;

Са ватром она га је спалила;

Са жрвњем она га је смрвила;

$<$ са ситом она га је разбацала $>43$

Његове остатке птице једу,

Дивље животиње једу његове делове,

Остаци од остатака се раздвајају.

40 Интересантно је да Какут (Caquot) овде види митолошки израз за феномен испаравања под дејством сунчеве светлости (уп. Ис 55:10), уп. J. Gray, Legacy of Canaan, 63.

41 Загигурно је да се овде рефлектује сукоб јахвеизма са локалним култом плодности. Сматра се да се у таквим приликама приносило Моту који је псоматран као Адонис. Уп. J. Gray, Legacy of Canaan, 65.

42 Треба да напоменемо да је Баалово тело већ пронађено и погребено. Ово је једна од неконзистентности. Међутим, ритуални текстови не препознају ову нелогичност. Ипак, уколико покушамо да пронађемо доследност, можемо се позвати на разликовање између умрлог тела и неуништивог дела који преживљава смрт остајући способан за реинкарнацију. Овај мит не представља метафизичку спекулацију, већ је етилошки по свом карактеру где смрт и погеб Баала и његово оживљавање одговарају ритуалима у вези са одумирањем и поновним рађањем вегетације. Уп. J. Gray, Legacy of Canaan, 67.

43 Глагол dr' не треба преводити по аналогији са уобичајеним значењем zr',,сејати“. Имамјно у виду да се овај глагол двапут преводи у значењу „расипати“ (уп. Суд 9:45; Зах 10:9), уп. John C. L. Gibson, Canaanite Myths and Legends, T\&T Clark International, ${ }^{2} 1978,19$; Осим тога, ова слика је укорењена дубоко у агрокултури. Наиме, овде видимо типичне кораке у процесу жетве, док се овај призор узима као митолошки парњак обичају који је практикован сваке године, а у коме је Мот представљен као дух смрти у житу коју треба одагнати. На тај начин принос би био десакрализован, односно погодан за људску употребу или би се тежило да семе остане здраво како би могло да се сади следеће године. УП. S.E. Loewenstann, The Ugaritic Fertility Myth - the Result of a Mistranslation, Israel Exploration Journal 12, no. 2 (1962): 87-88. 
Овде имамо јасну везу између мита и сезонских ритуала, у овом случају десакрализације првина жита како би били доступни за општу употребу. Такав обред је забележен у Лев 2:14 где се упућује на принос првина. ${ }^{44}$

Наговештај о Бааловом устајању из света мртвих, а са њим и последично буђење вегетације, имамо у Еловом сну (RTU:KTU 1.6.III.1-21 (136*137)):

Иако је (Баал) пострадао ( )

Гле! Моћни Баал је жив

Гле! Принц, Господар земље живи ${ }^{45}$

У сну Ела благотворног и милостивог

У виђењу творца свега створеног ${ }^{46}$

Небеса лију уље

Низ долину се спушта мед (...) ${ }^{47}$

Наиме, сушење растиња услед слабе влажности представљено је као силазак Баала у свет мртвих, при чему он са собом води и своје облаке, ветрове, армију коња̂, али и кишу (RTU:KTU 1.5 .7 (124)). Ипак, Баал ће устати из мртвих и заузети Мотов престо. Бааловом тријумфу претходио је обрачун Мота и Анат, при чему је Анат победила. ${ }^{48}$

44 Детаљније о овом имамо код Филона (De Sept. II, 20); Јосифа Флавија (Antiquitates III, 250); као и у Мишни (Menahoth X, 3-4 65a-66a). Поменута сведочанства датују овај ритуал 10. нисана. УП. Ј. Gray, Legacy of Canaan,

45 Титула $z$ bl b'l 'arş као Баалов епитет појављује се у BC II:KTU 1.3.I.3 (69); RTU:KTU 1.5.VI.10 (=1.6.I.42; 1.6.III.1) (126); 1.6.III.9 (=1.6.III.3; 111.21).IV.5 (138) (=1.6.IV.16). Ових девет појава заправо представљају комбинацију две независне титуле, при чему је друга ( $b$ 'l 'arş), иако нема потврде о другим појављивањима, паралелна са b'lt šmm rmm, „госпођа висина небеских“. Интересантно је мишљење према коме се 'arş односи на подземни свет (уп. KTU 1.108.1), имајући у виду улогу Баала као господара обоготворених мртвих. Треба имати у виду да се титула осам пута појављује у контексту Баалове смрти и зласка из доњег света. Међутим, има и оних који управо ову титулу виде као Баалову примарну с обзиром на на његов статус врховног божанства. Они који заступају овакво виђење позивају се на KTU 1.3.I.3 где се Баал тако ословљава. Сматра се да је оваква титула паралелна са акадским Enlil bēl šamě и erşetim „Енлил, господар небеса̂ и земље“ (CH I.5). A. Rahmouni (прр), Divine Epithets in the Ugaritic Alphabetic Texts (Handbook of Oriental Studies 93), Brill, 2008, 163-164.

46 Титула bny bnwt појављује се у BC II:KTU 1.4.II.11(77); 1.4.III.32(78); RTU:KTU 1.6.III.5 (=1.6.III.11) (136); 1.7.I.24 (129). У свих пет случајева примењује се на Ела као главу пантеона и оца човечанства и богова. Уп. А. Rahmouni (прр), Divine Epithets, 98-101.

47 Баала, међутим, даље траже, његова сестра, Анат која богињу сунца Шпш, која крстарећи небом и надзирући земљу зна све тајне живота и смрти, пита где је Баал, док Шпш заповеда да се излије пенушаво вино из бачве, и да без икакве стрепње сачека да пронађе Баала (1.6.IV.30-44). Међутим, интересантна је употреба фразе о меду и уљу (уп. Изл 3:8.17; Лев 20:24; Понз 26:9; Ам 9:13; Пс 65:12). УП. УП. W. Herrmann, "BAAL בעל ", y: K. van der Toorn et al. (прр), Dictionary of Deities and Demons in the Bible, Wm. B. Eerdmans Publishing Co., ${ }^{2} 1999,134$.

48 Треба имати у виду да је свођење мита о Баалу и Моту искчучиво на објашњење промене годишњих доба и, са њом у вези, плодношћу непримерено имајући у виду недослед- 
Након великих празнина у тексту, сусрећемо redivivus Баала ${ }^{49}$ који прети својим непријатељима (1.6.V.1-6 (140)), али његов тријумф је краткотрајан јер се након седам година ${ }^{50}$ Мот - опорављен од Анатових удараца - изнова појављује изазивајући Баала на коначни двобој (1.6.V.7-19 (140141)). Закључак овог божанског сукоба је, нажалост, изгубљен, али се може претпоставити да Мот признаје Баалову божанску доминтност. ${ }^{51}$ Истакнимо још и то да се у ВC II:KTU 1.3.II.39 (70); RTU:KTU 1.6.III.6-7 (136-137), 12-13 (137) Баал представља као чувар плодности земљишта. ${ }^{52}$

Када је реч о жртвоприношењу, RTU:KTU 1.148.I.1-5 (427-430), где се налази попис божанстава са жртвама које им се приносе, име Баала се помиње седам пута, што је у вези са горе поменутом појавом о седам Баала. Тако се Баалу приноси седам пута во и ован, ${ }^{53}$ док је, према TUAT II:KTU 1.39 , Баалу намењен један ован, а скупини Баала̂ једна јуница. Када је реч о листи жртава за одређене месеце, RTU:KTU 1.41.I.15 (=1.87) (348-356), конкретно, првог месеца Rischyena, почетка бербе грожђа, Баалу се приноси, такође, један ован, а скупини Баала једна јуница. Месеца Нiуara Баалу ратнику се приноси бик и ован четрнаестог дана (TUAT II:KTU 1.105.I.1, 306),

ности које са собом таква произвољна редукција носи: 1) Мотову телесину коју је Анат посејала у пољу су појеле птице. Овај детаљ очигледно није повезив са било каквом пољопривредном активности или плодношћу тла јер је заиста несрећан онај чији засад позобу птице; 2) након што је и Мот поново оживе, у свом обаћању Баалу помиње сејање семена у воду, што, такође, не може бити симол плодности; 3) након васкрсења оба божанства живе истовремено чиме се симбол сукцесивности укида; 4) Баалу је требало седам година да надвлада Мота након што је Мот васрсао, а исто толико је и трајао период Баалове смрти итд. Уп. U.Cassuto, Baal and Mot in the Ugaritic Texts, Israel Exploration Journal 12, no. 2 (1962): 77-86, [79-80];

49 Детаљније о феномену умирлог и оживљеног божанства: M. S. Smith, The Origins of Biblical Monotheism, 127-130.

50 Помен седам година овде само наизглед говори против годишњег пољопривредног циклуса. Међутим, Стари завет говори о суботњој - седмој - години као транзитном периоду када се земља оставља да почива (уп. Изл 23:10-11; Лев 25:3-7). Интересантно је тумачење према коме период од седам година као време после ког Мот устаје треба повезати са периодичним појавама глади. Имајмо у виду да се у наративу о Јосифу управо појављује након седам година изобиља (уп. 41:25.47.54). Осим тога, критичари који оспоравају теорију о митолошкој представи сезонског циклуса наводе како је потпуно неплаузибилно да мит наставља са перипетијама главног јунака након његовог излажења из доњег света. У другом опису немилосредног Мота (RTU:KTU 1.6.II.6-12 (133-134)) до изражаја долази његова крволочност, односно његов портрет као првобитног земаљског чудовишта (уп. ВC I:KTU 1.2.I.2 (260); Ис 25:8). УП. J. Gray, Legacy of Canaan, 76.

51 J. Gray, Legacy of Canaan, 75.

52 У KTU 1.13 се налази химан за коју један број тумача тврди да се њоме призива Баал да дарује плодност. Уп. W. Herrmann, ”BAAL בעל ", у: K. van der Toorn et al. (прр), Dictionary of Deities and Demons in the Bible, 134.

53 Поменуте животиње ће се још на неколико места у оквиру KTU 1.148 поменути као жртве намењене Баалу: уп. RTU:KTU 1.148.V.25.44 (427). 
осамнаестог дана принос је исти, при чему се бик као жртва за мир спаљује (TUAT II:KTU 1.105.I.5, 307). Осим тога, у храму Баала угаритског приноси cе 38 комада мање стоке, седам бикова и два овна (TUAT II:KTU 1.105.I.5, 310). 54 Пракса приношења овна и вола се задржава и током праничних месеци (уп. RCU:KTU 1.109.I.11). У dbh mlk („обреди жртвовања намењени цару“) (RCU:KTU 1.91.I.14) се, између осталих за које се приноси вино, помиње и Баал. Реч је о литургичком тексту који наводи имена угаритских божанстава за које цар излива вино добијено од угаритских градови. TUAT II:KTU 1.13 садржи химну, односно ритуални текст који Аната представља као прождрљиву јуницу, односно Баалову јуницу, чија утроба није познала зачеће, али с обзиром да текст говори о плодности људи, он неће детаљније бити тематизован.

\section{Закључак}

Представљањем два наратива KTU 1.16 III.2-8 и KTU 1.5 - 1.6, као и довођењем у везу са Ос 2 покушали смо да покажемо позадину Осијиног диспута са хананском религијском праксом. Сматрамо да је у даљем истраживању потребно расветлити и практични аспект култа плодности који би се тицао сексуланих ритуала као конкретних актуализација мита. Са једне стране, култ почива на миту, а са друге стране, култ свагда бива актуалан кроз низ ритуалних радњи које обезбеђују непрестано понављање мита. Са позиција тумача Ос 2 ово је посебно важно због помена љубавника Осијине жене, што је често био траг којим се покушавала истражити култна позадина сексуланих елемената у културама Ханана, Израиља, Угарита, Вавилона, односно култне или сакралне проституцији, ритуалног одузимања невиности, сакралних венчања, као и других сексуланим елемнетима.

54 Уп. L. R. Fisher, A New Ritual Calendar from Ugarit, The Harvard Theological Review Vol. 63, No. 4 (Oct., 1970), 485-501, [486-493]. 


\section{Литература}

Извори:

Biblia Hebraica Stuttgartensia (ВHS), K. Elliger/W.Rudolph et al. (прр.), Deutsche Bibelgesellschaft, Stuttgart, 1966/67.

Septuaginta (LXX), Alfred Rahlfs (прр.), друго издање: Robert Hanhart, Deustche Bibelgesellschaft, Stuttgart, 2006.

Novum Testamentum Graece, (Nestle-Aland 28th Edition), Deutsche Bibelgesellschaft, Stuttgart, 2013.

KTU 1.1: The Ugaritic Baaal Cycle: Introduction with Text, Translation and Commentary of KTU/CAT 1.1-1.2 (Supplements to Vetus Tetsamentum55/I), Mark S. Smith (прр), Brill Academic Publishers, 1994, 116-210. [BC I:KTU 1.1]

KTU 1.2: The Ugaritic Baaal Cycle: Introduction with Text, Translation and Commentary of KTU/CAT 1.1-1.2 (Supplements to Vetus Tetsamentum55/I), Mark S. Smith (прр), Brill Academic Publishers, 1994, 211-356. [BC I:KTU 1.2]

KTU 1.3: The Ugaritic Baaal Cycle: Introduction with Text, Translation and Commentary of KTU/CAT 1.3-1.4 (Supplements to Vetus Tetsamentum55/II), /Wayne T. Pitard (прр), Brill Academic Publishers, 2009, 87-390. [BC II:KTU 1.3]

KTU 1.4: The Ugaritic Baaal Cycle: Introduction with Text, Translation and Commentary of KTU/CAT 1.3-1.4 (Supplements to Vetus Tetsamentum55/II), /Wayne T. Pitard (прр), Brill Academic Publishers, 2009, 391-697. [BC II:KTU 1.4]

KTU 1.5: Religious Texts from Ugarit (Biblical Seminar 53), Nicolas Wyatt (прр), Sheffield Academic Press, ${ }^{2} 2002$, [RTU:KTU 1.5]

KTU 1.6:, Religious Texts from Ugarit (Biblical Seminar 53), Nicolas Wyatt (прр), Sheffield Academic Press, ${ }^{2} 2002,115-148$. [RTU:KTU 1.6]

KTU 1.10: Religious Texts from Ugarit (Biblical Seminar 53), Nicolas Wyatt (прр), Sheffield Academic Press, ${ }^{2} 2002$, 155-161. [RTU:KTU 1.10]

KTU 1.13: Religious Texts from Ugarit (Biblical Seminar 53), Nicolas Wyatt (прр), Sheffield Academic Press, ${ }^{2} 2002,169-176$. [RTU:KTU 1.13]

KTU 1.16: Religious Texts from Ugarit (Biblical Seminar 53), Nicolas Wyatt (прр), Sheffield Academic Press, ${ }^{2} 2002,219-243$. [RTU:KTU 1.16]

KTU 1.17: Religious Texts from Ugarit (Biblical Seminar 53), Nicolas Wyatt (прр), Sheffield Academic Press, ${ }^{2} 2002$, [RTU:KTU 1.17]

KTU 1.19: Religious Texts from Ugarit (Biblical Seminar 53), Nicolas Wyatt (прр), Sheffield Academic Press, ${ }^{2} 2002,246-314$. [RTU:KTU 1.19]

KTU 1.39 (RS 24.246): Texte aus der Umwelt des Alten Testaments II: Orakel, Rituale Bau- und Votivinschriften Lieder und Gebete, Wilhelmus C. Delsman/Manfried Dietrich et al. (прр), Gütersloher Verlagshaus Gerd Mohn, 1986/87/88/89/91, 308310. [TUAT II:KTU 1.39]

KTU 1.47.1.118, RS 20.24: Religious Texts from Ugarit (Biblical Seminar 53), Nicolas Wyatt (прр), Sheffield Academic Press, ${ }^{2} 2002,360-363$. [RTU:KTU 1.47.1.118]

KTU 1.91: Ritual and Cult at Ugarit (Writings from Ancient World 10), Dennis Pardee (прр), Society of Biblical Literature, 2002, 214-216. [RCU:KTU 1.91] 
KTU 1.101: Religious Texts from Ugarit (Biblical Seminar 53), Nicolas Wyatt (прр), Sheffield Academic Press, ${ }^{2} 2002$, 388-391. [RTU:KTU 1.101]

KTU 1.105 (RS 24.249): Texte aus der Umwelt des Alten Testaments II: Orakel, Rituale Bau- und Votivinschriften Lieder und Gebete, Wilhelmus C. Delsman/Manfried Dietrich et al. (прр), Gütersloher Verlagshaus Gerd Mohn, 1986/87/88/89/91, 314315. [TUAT II;KTU 1.105]

KTU 1.109 (RS 24.253/24.284): Ritual and Cult at Ugarit (Writings from Ancient World 10), Dennis Pardee (прр), Society of Biblical Literature, 2002, 26-34. [RCU:KTU 1.109]

KTU 1.119: Religious Texts from Ugarit (Biblical Seminar 53), Nicolas Wyatt (прр), Sheffield Academic Press, ${ }^{2} 2002,416-423$. [RTU: KTU 1.119]

Секундарна лииеерайура

Avaly-Darshan, Noga, "Baal, Son of Dagon: In Search of Baal's Double Paternity", Journal of the American Oriental Society, Vol. 133, No.4 (October-December 2013); 651-657.

Barstad, M. Hans, The Religious Polemics of Amos: Studies in the Preaching of Amos 2,7B-8; 4,1-13; 5,1-27; 6,4-7; 8,14 (Supplements to Vetus Testamentum 34), Brill Academic Publisher, 1984.

Botica, Aurelian, Weather, Agriculture, and Religion in the Ancient Near East and in the Old Testament, Perichoresis, Volume 11, Issue 1 (2015):95-122.

Botica, Aurelian,"The Theophoric Element Ba'al in Ancient Phoenician Inscriptions", Perichoresis, vol. 10.1 (2012): 67-93.

Cassuto, Umberto, "Baal and Mot in the Ugaritic Texts", Israel Exploration Journal 12, no. 2 (1962): 77-86.

Cassuto, Umberto, The Palace of Baal, Journal of Biblical Literature, Vol. 61. No.1, (1945): 51-56.

Cassuto, Umbro, "Baal and Mot in the Ugaritic Texts", Israel Exploration Journal Vol. 12, No.2 (1962):77-86.

Cho, Sang-yôl, Lesser Deities in the Ugaritic Texts and the Hebrew Bible: A Comparative Study of their Nature and Roles, Gorgias Press, 2007.

Davis, I. Graham, Hosea (New Century Bible Commentary), Eerdmans Publishing Co, 1992.

Gibson, C. L John, Canaanite Myths and Legends, T\&T Clark International, ${ }^{2} 1978$.

Ginsberg, H. L., W. F. Albright, and Elimelech, The Legend of King Keret: A Canaanite Epic of the Bronze Age, Bulletin of the American Schools of Oriental Research. Supplementary Studies, no. 2/3 (1946): 1-50.

Gray, John, Legacy of Canaan: The Ras Shamra Texts and Their Relevance to the Old Testament, Brill Academic Publishers, 1965.

Irwin, P. Brian, "Baal and Yahweh in the Old Testament: A Fresh Examination of the Biblical and Extra-Biblical Data" (Ph.D. Dissertation, University of St. Michael's College, 1999).

Jacobs, Vivian/Jacobs, Issac Rosensohn, The Myth of Mot and 'Al'eyan Ba'al, The Harvard Theological Review, Vol. 38, No. 2, (1945), 77-109. 
Karel Van Der Toren/Bob Becking/Pieter W. Van Der Horst (прр), Dictionary of Deities and Demons in the Bible, Wm. B. Eerdmans Publishing Co, 1999.

Karel, van der Toorn, et al. (прр), Dictionary of Deities and Demons in the Bible, Wm. В. Eerdmans Publishing Co., ${ }^{2} 1999$.

Kelle, E. Brad, Megan Bishop Moore, Israel's Prophets and Israel's Past: Essays on the Relationship of Prophetic Texts and Israelite History in Honor of John H. Hayes (Library of Hebrew Bible - Old Testament Studies), T \& T Clark International, 2006.

L. R. Fisher, “A New Ritual Calendar from Ugarit”, The Harvard Theological Review Vol. 63, No. 4 (Oct., 1970), 485-501.

Loewenstann, E. Samuel, "The Ugaritic Fertility Myth - the Result of a Mistranslation”, Israel Exploration Journal 12, no. 2 (1962): 87-88.

Margalit, Baruch, The Legend of Keret, y Wilfred G. E. Watson/Nocolas Wyatt (прр), Handbook of Ugaritic Studies, Brill Academic Publishers, 1999.

May, G. Herbert, “An Interpretation of the Names of Hosea's Children”, Journal of Biblical Literature, vol. 55, no. 4, (1936): 285-291.

Moughtin-Mumby, Sharon, Sexual and Martial Metaphors in Hosea, Jeremiah, Isaiah, and Ezekiel (Oxford Theological Monographs), Oxford University Press, 2008.

Nelson, D. Richard, "Priestly Purity and Prophetic Lunacy: Hosea 1:2 and 9:7", y Lester L. Grabbe/Alice Ogden Bellis (прр), The Priests in the Prophets: The Portrayal of Priests, Prophets and other ReligiousSpecialists in the Latter Prophets (JSOTSup). T\&T Clark International, 2004, 115-33.

Rahmouni, Aicha, (прр), Divine Epithets in the Ugaritic Alphabetic Texts (Handbook of Oriental Studies 93), Brill, 2008.

Routledge, Robin, "Hosea's Marriage Reconsidered", Tyndale Bulletin 69.1 (2018):25-42.

Smith, S. Mark, The Origins of Biblical Monotheism: Israel's Polytheistic Background and the Ugaritic Texts, Oxford Univerity Press, 2001.

Wounde, van der Irene, Three Classical Prophets: Amos, Hosea, y: Micah, Richard Coggins et al. (прр), Israel's Prophetic Tradition: Essays in Honour of Peter R. Ackroyd, Cambridge University Press, 1982, 32-57.

Wyatt, Nicolas, “The Titles of the Ugaritic Storm-God”, Ugarit-Forschung 24, (2007), 403-424. 

Branislav Ivić
University of Belgrade
Faculty of Orthodox Theology
Department for Biblical Studies
branislavivic95@gmail.com

\title{
INTERPRETATION OF HOS.2 IN THE CONTEXT OF RELIGIOUS POLEMIC WITH THE CANAANITE CULT
}

\begin{abstract}
Summary
The Article deals with the explanation of Hos. 2 in the context of religious polemic with the Canaanite cult. First of all, the Article deals with the cult of Baal that is related to fertility cult. The Article is trying to explain the way prophet Hosea presents the relationship of Yahweh and Israel, through metaphor of marriage as a dominant theme through the first three chapters of the book. He is comparing Yahweh with the loyal husband and Israel is presented as a deceitful woman who takes pleasure in relations with different lovers, namely with Baal(s) as an exponent of the Canaanite religion. The text takes two key narratives when speaking about the fertility cult KTU 1.16 III.2-8 and KTU 1.5-1.6, comparing them with Hos. 2 as a manifesto of the Book of the Twelve. Instead of appointing all the earthly goods to Yahweh, they are giving their gratitude to Baal. As consequence of its complexity the questions related to the fertility cult stay overlooked. The history or reception (Wirkungsgeschichte) by studying Hos.2 tried to get a trace of sacral prostitution and other sexual activities with practical sacral aspects. Further on that subject, on another occasion.
\end{abstract}

Keywords: Yahweh, Baal, Hosea, fertility cult, the Canaanite religion, syncretism 